\title{
Teknologi Informasi Dan Komunikasi Sebagai Media Baru Dalam Komponen Pembelajaran
}

\author{
Subria Mamis \\ Fakultas Ushuluddin Adab dan Dakwah, IAIN Kendari \\ e-mail: subriamamis@iainkendari.ac.id
}

\begin{abstract}
Abstrak
Tulisan ini dimaksud untuk mendeskripsikan media baru, Ujian Nasional Berbasis Komputer (UNBK), sebagai wahana evaluasi pembelajaran yang bertujuan untuk melihat sejauh mana teknologi informasi dan komunikasi merambah kedunia pendidikan. Pengumpulan data dilakukan dengan wawancara mendalam kepada pihak terkait, observasi dan juga dokumentasi. Hasil-hasil temuan saintifik yang diperoleh adalah bahwa Media Baru secara kualitas memberikan evaluasi yang unggul dengan menampilkan sifatnya yang memberikan efisiensi biaya, bahan, dan waktu penyelenggaranan ujian. Dengan media baru jangkauan wilayah yang luas dapat dicapai. Selain itu, sifat transparansinya dalam mekanisme penyajian soal dan juga dalam keamanan naskah menjadi akibat hadirnya new media di ranah pendidikan. Tulisan ini dikaji dengan pendekatan teori New Media yang merefleksikan media evaluasi belajar siswa yang ditandai dengan penggunaan jaringan internet, Teori Determinisme Teknologi yang mengimplikaskan penggunaan teknologi sebagai faktor dominan yang berpengaruh dalam media evaluasi belajar, Teori Konstruktivisme pendidikan yang megindikasikan siswa belajar aktif dengan kehadiran new media dalam evaluasi belajar dan juga Teori Difusi Inovasi yang merepresentasikan inovasi kebijakan pemerintah yang didiseminasikan kepada sekolah-sekolah penyelenggara ujian berbasis komputer. Sehingga, dapat disimpulkan bahwa presensi new media mengubah perubahan perilaku dari satu sisi evaluasi pembelajaran.
\end{abstract}

\section{Kata Kunci : Media baru, Evaluasi Pembelajaran, Ujian Nasional Berbasis Komputer}

\begin{abstract}
This article is intended to describe the new media for the ComputerBased National Examination (UNBK) as a vehicle for evaluating learning that aims to see the extent to which information and
\end{abstract}


communication technology has penetrated the world of education. Data collection was carried out by in-depth interviews with related parties, observation and even documentation. The scientific findings obtained are that New Media gives a superior evaluation quality by displaying its properties that provide cost efficiency, materials, and test execution time. With new media a wide area coverage can be achieved. In addition, the transparency in the mechanism for presenting questions and also in safeguarding texts is the result of the presence of new media in the field of education. This paper discusses the New Media theory approach which reflects the media for evaluating student learning characterized by the use of internet networks; The theory of technological determinism; which implies the use of technology as the dominant influencing factor in learning evaluation media, the theory of educational constructivism; which indicates students learn actively with the presence of new media in learning evaluation, and also the Innovation Diffusion Theory; which represents government policy innovation disseminated to school administrators computer based exam. So, it can be concluded that the presence of new media changes behavior change from one side of learning evaluation.

Keywords: New Media, Learning Evaluation, Computer-Based National Examination

\section{A. Pendahuluan}

"Nothing remains untouched by communication technology" sebuah adagium Griffin (2003:344) yang membenarkan bahwa komunikasi menyentuh pelbagai sisi kehidupan manusia. Bagaimana tidak, media baru komputer yang oleh Daniel Chandler dan Red Munday secara sederhana disamakan dengan Teknologi informasi lahir beriringan dengan kelahiran peradaban manusia. Kecenderungan manusia untuk beradaptasi dengan cepat terhadap perkembangan teknologi ditujukan agar dapat berkomunikasi dengan lebih cepat dan lebih baik. Peradaban manusia yang semakin maju dan berkembang pesat itu menuntut adanya media baru yang efisien dan efektif. Sebut saja, 
dalam dunia pendidkan, komputer dan internet sebagai media baru dalam satu sistem komponen pembelajaran, bukan hanya sebagai media pembelajaran namun juga menjarah ke media evaluasi belajar siswa. Sehingga, hal ini membenarkan hubungan antara teori komunikasi dan teori pembelajaran, dimana evaluasi menjadi irisan yang mejadi titik fokus dalam tulisan ini. Evaluasi sejatinya dibutuhkan sebagai eksistensi tolak ukur dalam rangka pemetaan mutu program satuan pendidikan, dalam hal ini dikhususkan pada satuan tingkat pendidikan SMA dan sederajat (SMK) demi mencapai Standar Kompetensi Lulusan (SKL) pada mata pelajaran tertentu secara nasional (UU Sisdiknas No 20 tahun 2003 Pasal 58 ayat 2 dan PP No. 19 tahun 2005 Pasal 63 ayat 1 tentang Standar Nasional Pendidikan). Selain itu, evaluasi yang menjadi irisan bidang ilmu komunikasi dan pendidikan juga telah diamanatkan kepada pemerintah secara nasional dalam memajukan ilmu pengetahuan dan teknologi dengan menjunjung tinggi nilai-nilai agama dan persatuan bangsa untuk kemajuan peradaban serta kesejahteraan umat manusia (UUD 1945). Sehingga, visi dan misi sistem pendidikan nasional dapat tergapai. Visi sebagai pranata sosial yang kuat dan berwibawa agar semua warga negara Indonesia berkembang menjadi manusia yang berkualitas; dan misi untuk membantu dan memfasilitasi pengembangan potensi anak bangsa secara utuh sejak usia dini sampai akhir hayat dalam rangka mewujudkan masyarakat belajar.

Media dalam evaluasi dalam hal ini difokuskan pada teknis-tes yaitu serentetan pertanyaan atau alat lain yang digunakan untuk mengukur kemampuan atau bakat yang dimiliki oleh individu atau kelompok. Teknik evaluasi tes kemudian dikhususkan lagi pada tes sumatif atau evaluasi sumatif yaitu tes yang dilakukan setelah berakhirnya pemberian sekelompok atau sebuah program yang lebih besar. Teknik evaluasi tes sumatif tersebut direfleksikan dalam Program Ujian Nasional (UN) pada tingkatan tahap akhir jenjang pendidikan SMA maupun SMK. 
Metode evaluasi yang diapakai sayangnya belum mempresentasikan alat evaluasi yang diinginkan. Kecurangan kerap kali dilakukan mengingat sekolah mempertahankan citra yang baik. Lebih jauh lagi, alat tes tersebut sangat syarat dengan waktu dan biaya yang tidak sedikit sehingga penyelenggaraannya dianggap terlalu kompleks. Pengiriman paket UN tersebut melibatkan banyak pihak seperti kepolisian sebab kerahasiaan paket soal yang mesti dijaga, sehingga dalam pendistribusian paket soal membutuhkan waktu dan biaya yang signifikant. (Hasil Wawancara Narasumber)

Kecanggihan teknologi membantu menjawab fenomena yang terjadi dalam UNKP. Sebut saja UNBK sebagai alat media yang inovatif dalam dunia pendidikan. Selain merupakan inovasi dalam ranah pendidikan, dimana teknologi komputer sering diperuntukkan untuk media pembelajaran, kali ini perangkat tersebut pun merambah ke media evaluasi UN-CBT yang diidentifikasi menjadi salah satu metode menjawab fenomena kecurangan dengan sifat new media yang transparansi dan menghadirkan efisiensi biaya dalam Ujian Nasional Berbasis Kertas dan Pensil (UNKP) untuk tujuan yang sama yaitu pencapaian kompetensi lulusan secara nasional pada mata pelajaran tertentu (Peraturan BSNP 0031/BNSP/III/2015).

Pemanfaat Inovasi Media Ujian Nasional Berbasis Kompetensi menjadi salah satu rentetan peradaban ilmu pendidikan yang saling beradaptasi dengan teknologi informasi dan komunikasi. Bagaimana tidak, Ujian Nasional yang awalnya hanya dilakukan sebatas sistem LJK (Lembar Jawaban Komputer) kemudian bertransformasi ke sistem pelaksanaan Ujian Nasional dengan menggunakan komputer yang dilengkapi dengan perangkat lunak (software) yang khusus sebagai media ujiannya serta penggunaan internet yang semakin menghadirkan media baru. Selain merupakan inovasi media dalam ranah pendidikan, dimana teknologi komputer sering diperuntukkan untuk media pembelajaran, kali ini perangkat tersebut pun merambah ke media evaluasi UN- 
CBT yang diidentifikasi menjadi salah satu metode menjawab fenomena kecurangan dengan sifat new media yang transparansi dan menghadirkan efisiensi biaya dalam Ujian Nasional Berbasis Kertas dan Pensil (UNKP) untuk tujuan yang sama yaitu pencapaian kompetensi lulusan secara nasional pada mata pelajaran tertentu (Peraturan BSNP 0031/BNSP/III/2015). Ekspansi komunikasi bermedia dalam pendidikan seperti UNBK telah didominasi oleh peran hasil adopsi dari inovasi kajian komunikasi bermedia yang memiliki sifat transparansi dengan pemanfaatan teknologi digital. Walau bagaimanapun, sejatinya, suatu yang baru selalu mendatangkan masalah. Kita dapat melihat kebijakan UNBK yang secara nyata bermedia baru memiliki kendala untuk diselenggarakan secara serentak mengingat pengelolaan dari berbagai segi yang harus dibenahi baik yang sifatnya teknis seperti infrastuktur media komputer maupun non-teknis seperti kemampuan (skill) dalam pengambilan keputusan oleh kepala sekolah, kreativitas guru dan kesiapan peserta didik dalam menghadapi program tersebut.

Melihat fenomena media baru diatas, penulis fokus untuk membahas Teknologi Informasi Dan Komunikasi Sebagai Media Baru dalam Komponen Pembelajaran yang memperlihatkan aspek media baru komunikasi dalam bidang pendidikan di Kota Kendari, sehingga penelitian ini menjadi berbeda dengan apa yang telah diteliti sebelumya oleh Arif Nurhidayat yang menganalisis pengelolaan pada Sekolah Menengah yang menjadi perintis penyelenggara UNBK di Provinsi Yogyakarta. Diharapkan hasil penelitian ini dapat menambah khasanah ilmu pengetahuan terutama kajian ilmu komunikasi yang disinergikan dengan ilmu pendidikan. Selain itu, secara praktis hasil penelitian ini diharapkan menjadi referensi bagi praktisi dalam bidang komunikasi mendapatkan gambaran tentang esensi new media yang hadir di ranah pendidikan.

\section{B. Metode}


Metode yang digunakan dalam tulisan ini adalah metode kualitatif dengan menggunakan dua jenis sumber data yaitu: (1) Data primer yaitu data yang diperoleh langsung dari hasil observasi dan wawancara mendalam untuk mendapatkan data melalui fakta-fakta lapangan. (2) Data sekunder yaitu data merupakan data yang diperoleh dari hasil telaah dokumen dan laporan-laporan yang dianggap relevan dengan permasalahan penelitian. (Moleong, 2004)

Adapun teknik pengumpulan data dalam tulisan ini ialah dengan melakukan Wawancara mendalam, Observasi, dan Dokumentasi. Pengumpulan data dilakukan peneliti melalui wawancara berdasarkan daftar pertanyaan yang sudah disiapkan terlebih dahulu, namun tidak terpaku pada daftar tersebut, karena peneliti tetap mengembangkan pertanyaan untuk menggali informasi yang dibutuhkan. Informan dalam penelitian ini dipilih dengan menggunakan teknik purposive sampling yaitu teknik pengambilan sampel dengan pertimbangan tertentu dimana peneliti menentukan sendiri informan yang diambil dengan pertimbangan bahwa yang bersangkutan mengetahui dan memahami betul inti permasalahan yang sedangditeliti.

Metode kedua yaitu observasi. Metode ini adalah pengumpulan data yang melibatkan partisipasi peneliti secara langsung baik dengan cara mengamati, mendengarkan yang dikatakan narasumber atau pihak terkait dan menanyai orang disekitar selama jangka waktu tertentu (Sugiyono; 2012). Tulisan ini melihat skema pengadaan UNBK di sekolah-sekolah yang mengadakan UNBK.

Teknik pengumpulan data yang ketiga yang digunakan adalah Dokumentasi yakni teknik pengumpulan data dengan dokumen atau yang tidak langsung ditujukan pada subjek penelitian. Adapun dokumen yang digunakan adalah surat keputusan, literatur ilmiah, laporan, jurnal dan arsip yang berkaitan dengan media baru dan pengelolaan UNBK. Analisis data yang diaplikasikan pada penelitian ini ialah analisis data model Miles Huberman 
yang terdiri dari reduksi data, display data, penarikan kesimpulan dan verifikasi (Sugiyono, 2013).

\section{Hasil dan Pembahasan}

New Media dalam evaluasi belajar siswa di Kota Kendari yang memperlihatkan penerapan Inovasi media disadari lebih menuai manfaat dibandingkan ujian nasional secara konvensional, UNPK (Ujian Nasional Pensil dan Kertas). Manfaat yang diperoleh antara lain efisisensi biaya, efektivitas waktu, transparansi atau kejujuran dalam pelaksanaan ujian dan yang lebih terpenting adalah motivasi belajar yang dibangun oleh para peserta ujian itu sendiri. Namun, semua yang baru sejatinya memiliki problem tersendiri, begitu halnya dengan munculnya media baru sebagai hasil difusi inovasi dalam teknologi komunikasi di bidang pendidikan. Belum meratanya teknologi informasi dan komunikasi yang dimiliki menjadi salah satu kendala melaksanakan UNBK. Meski demikian, keputusan untuk melakukan evaluasi belajar UNBK tetap dilakukan. Pengambilan keputusan dilakukan melalui rapat internal para guru sekolah dan peminjaman komputer dari sekolah lain dan laptop-laptop peserta ujian.

Peminjaman perangkat komputer dari sekolah-sekolah lain dilakukan dengan bersurat ke masing-masing sekolah. Sedangkan, peminjaman laptop para siswa diawali dengan bersurat kepada orang tua peserta UNBK atau siswa kelas XII yang didalamnya berisi tentang himbauan pada orang tua untuk rapat di sekolah yang dituju. Rapat eksternal dengan pihak orang tua tersebut ditujukan agar para orang tua berkenan meminjamkan laptop yang akan dipakai ketika UNBK dengan jaminan kerusakan akan ditanggung oleh sekolah jika diperoleh kerusakan pada alat yang dipinjamkan tadi. Sehingga, UNBK di sekolah penyelenggara dapat memenuhi syarat yang tertulis pada POS UNBK yaitu 1 client : 3 peserta ujian, dibuktikan dengan jumlah komputer dan laptop client sebanyak 150 untuk 466 jumlah siswa. Hal terakhir 
menjadi pendukung terselenggaranya progrma difusi inovasi dari Pemerintah ialah Sumber Daya Manusia yang mumpuni. Guru-guru sekolah yang kompeten dalam bidang TIK, terdiri dari 1 orang teknisi dan 4 orang proktor. Memiliki tanggung jawab yang lebih besar dalam penyelenggaraan UNBK. Di samping itu, Pelatihan oleh Pemerintah pusat ditujukan untuk teknisi dan proktor se-Nasional. Dari pelatihan tersebut mereka diberikan materi yang membahas tentang bagaimana syarat komputer yang digunakan, bagaimana cara mensetting komputer server dan client, menginstal aplikasi Virtual BOX yang didapat dari pelatihan proktor dikomputer server lokal sekolah, lalu dilanjutkan dengan pembuatan yang namanya Virtual Machine dan aplikasi CBT Sync di komputer server. Lalu setelah berhasil diinstal aplikasi CBT Sync dijalankan untuk mengaktifkan sistem agar data server lokal sekolah dapat terlihat di server pusat.

Setelah itu, berkaitan dengan proses sinkronisasi dan downloading soal UNBK serta nanti pada saat pelaksanaan dipergunakan untuk meminta TOKEN pada server pusat untuk mengakses sistem UN CBT oleh peserta ujian. Setelah menginstal aplikasi browser chrome pada komputer client. TOKEN itu adalah kode seperti password yang digunakan oleh peserta ujian untuk mengakses soal.

Hal yang tak kalah pentingnya ialah terkait kesiapan siswa peserta yang menjadi objek sekaligus subjek dari new media untuk mendapatkan pengayaaan dari para guru bidang studi UNBK dan simulasi penggunaan new media. Tryout atau simulasi UNBK dari Puspendik dilakukan guna untuk melatih siswa melakukan ujian dengan media komputer yang baru mereka lakukan. Tulisan ini berdalih dengan beberapa teori komunikasi. Teori New Media, Teori Determinisme Media, Teori Pendidikan Konstruktivisme, dan Difusi Inovasi adalah teori-teori komunikasi yang relevan digunakan oleh 
penulis untuk secara nyata merefleksikan new media dalam peradaban manusia di bidang pembelajaran.

\section{a) Teori New Media}

Teori yang dikembangkan oleh Pierre Levy ini mengemukakan bahwa new media merupakan teori yang membahas mengenai perkembangan media dari konvensional ke era digital. New media sebagai buah dari perkembangan teknologi komunikasi telah mengantarkan manusia pada zaman baru. Hal ini sesuai apa yang digagas oleh Williams dalam Rakhmat (2007)

"...the contemporary explosion in communication technologiescomputers, satelits, tape, disc, microprocessors, and new telephone and radio service-are perceptibly changing the nature of our human environment".

Bentuk-bentuk komunikasi baru ini kebanyakan berbentuk visual mempengaruhi sosial, ekonomi, politik, dan juga pendidikan. Hal ini tampak dari Ujian Nasional Berbasis Komputer yang berkembang dari Ujian Nasional Berbasis Pensil dan Kertas. Dua pandangan yang dikemukakan oleh Pierre Levy terkait new media, yaitu:

(1) Pandangan interaksi sosial, yang membedakan media menurut kedekatannya dengan interaksi tatap muka. Pierre Levy memandang World Wide Web (WWW) sebagai sebuah lingkungan informasi yang terbuka, fleksibel, dan dinamis, yang dapat mengarahkan manusia berorientasi pengetahuan yang baru dan juga terlibat dalam dunia demokratis tentang pembagian mutual dan pemberian kuasa yang lebih interaktif dan berdasarkan pada masyarakat.

(2) Pandangan integrasi sosial, yeng merupakan gambaran media bukan dalam bentuk informasi, interaksi, atau penyebarannya, tetapi dalam bentuk 
ritual, atau bagaimana manusia menggunakan media sebagai cara menciptakan masyarakat. Selain menjadi instrumen teknologi informasi dan komunikasi, atau cara untuk nteres secara personal, Media juga menyatukan manusia dalam beberapa bentuk masyarakat dan memberi kita rasa saling memiliki. (Solomon; 2011) Definisi lain mengemukakan, new media merupakan digitalisasi dari konsep pemahaman yang berpartisipasi dengan perkembangan zaman tentang teknologi dan sains, dari semula yang bersifat manual menjadi otomatis, dan dari semua yang bersifat rumit menjadi ringkas (Napitupulu; 2011). Tulisan ini menggunakan teori new media karena UNBK memanfaatkan new media sebagai media yang dapat menjawab fenomena kecurangan karena sifat transparancy yang dimilikinya dan juga agar Ujian Nasional diselenggarakan dengan lebih efektif dan efisien. UNBK sebagai media evaluasi sumatif yang baru mempertunjukkan kepada kita akan kemudahan dalam Ujian Nasional.

Tidak seperti ketika UN-PBT, soal-soal dari pusat (Jakarta) tidak perlu lagi melibatkan tim dari pendidikan Provinsi (diknas Prov) yang dikawal oleh anggota kepolisian (Polsek/polres) untuk sampai ke sekolah masingmasing. Namun, cukup dengan downloading soal yang telah disediakan timpuspendik dengan kode token pada saat Ujian dilaksanakan, soal-soal tersebut masuk ke komputer setiap sekolah yang terdaftar sebagai penyelenggara UNBK. Terlihat sungguh efeisien dalam biaya, efektif dalam mencapai tujuan UN, dan tentunya bersifat terbuka (transparancy) tanpa kecurangan baik yang sifatnya material seperti uang maupun bocornya soal oleh sebab keterlibatan new media yang terbungkus dalam teknologi pembelajaran untuk tes sumatif. Hal ini dikuatkan dengan ciri utama new media, diantaranya kesalingterhubungan, dapat terakses, maupun interaktivitasnya yang membuat sesuatu yang rumit menjadi mudah. (Lievrow dan Livingstone: 2006) 
Hal tersebut sesuai dengan apa yang digagas oleh Bolter dan Grusin dalam bukunya Remediation; Understanding New media (2000) yang mendeskripsikan sifat new media yang beriringan antara jarak kedekatan dan sifat keterbukaan.

Like other media since the Renaissance inparticular perspective painting, photography, film, and television-new digital media oscillate between immediacy and hypermediacy, between transparency and opacity.

\section{b) Teori Determinisme Teknologi}

Teori ini mendeskripsikan bahwa penemuan atau perkembangan teknologi komunikasi mampu merubah kebudayaan dan eksistensi manusia. Perubahan pola kehidupan masyarakat menjadi dampak penggunaan media yang berkembang seiring perubahan zaman dan teknologi di dalamnya. Salah satunya adalah perkembangan teknologi pendidikan yang merubah sistem evaluasi siswa dari yang manual, Ujian Nasioanl Polpen dan Kertas hingga digantikan posisinya oleh new media dengan sistem Ujian Nasional Berbasis Kompetensi. Terlihat, perubahan media sebagai buah teknologi menjadi unsur yang menentukan atau determinis dalam perilaku manusia, pada ujian siswa sebagai contoh kecilnya.

Perkembangan teknologi komunikasi tersebut menjadikan manusia kemudian hidup di dalam apa yang disebut sebagai "global village". Media massa pada era ini mampu membawa manusia mampu untuk bersentuhan dengan manusia yang lainnya, kapan saja, di mana saja, seketika itu juga.

Seringkali pertanyaan yang diajukan ketika berbicara tentang komunikasi

adalah untuk apa kita berkomunikasi, Fungsi komunikasi atau mengapa kita memerlukan komunikasi. Namun sedikit sekali yang melandasi pertanyaan-pertanyaan tersebut pada perkembangan teknologi komunikasi manusia dari hal-hal yang sederhana hingga teknologi 
tercanggih dewasa ini. Perkembangan teknologi itu tentu tidak dapat terlepas dari inovasi-inovasi yang diciptakan manusia. Manusia dengan kemampuannya dan fungsinya sebagai individu sosial yang berinteraksi dengan individu lain berupaya untuk menciptakan komunikasi dan media komunikasi yang efektif, cepat dan mobile.

Inti dari teori McLuhan adalah determinisme teknologi adalah penemuan atau perkembangan teknologi komunikasi itulah yang sebenarnya yang mengubah kebudayaan manusia. Jika Karl Marx berasumsi bahwa sejarah ditentukan oleh kekuatan produksi, maka menurut McLuhan eksistensi manusia ditentukan oleh perubahan mode komunikasi. Terlihat UN-CBT menjadi segi yang bersinggungandengan media massa.

McLuhan juga menyebutkan bahwa media massa adalah ekstensi atauperpanjangan dari inderawi manusia (extention of man). Baik pemerintah pusasebagai pihak penyelenggara UNBK maupun pihak sekolah dengan berbagakalangan membuktikan bahwa jangkauan antara kedua pihak tidak bukan hanya diperpanjang terhadap suatu tempat, peristiwa, informasi, tapi juga menjadikan hidup kita lebih efisien. Lebih dari itu media juga membantu mereka dalammenafsirkan perubahan kehidupan.

Medium is the message. Perspektif McLuhan menyebutkannya sebabmedia itu sendiri lebih penting daripada isi pesan yang disampaikan oleh mediatersebut. Media UNBK, yang didalamnya terdapat aplikasi xmbro untukdigunakan ketika ujian. Mungkin isi sofware berupa soal-soal UN di komputeatau laptop penting atau menarik, namun jauh lebih penting adalah presenskomputer atau laptop itu sendiri. Seperti halnya Media Televisi, Komputer jugadengan kehadirannya saja sudah menjadi penting, bukan lagi tentang ispesannnya. Kehadiran media massa telah lebih banyak mengubah kehidupanmanusia, lebih dari apa isi pesan yang mereka sampaikan. 
Mc Luhan yang menganggap bahwa inovasi-inovasi dalam bidangteknologilah yang lebih banyak pengaruhnya terhadap perkembangan di dalammasyarakat. McLuhan memilih teknologi informasi sebagai teknologi yangterpenting, yang paling mampu menyebabkan perubahan di dalam masyarakat.

\section{c) Teori Pendidikan Konstruktivisme}

Konstruktivisme merupakan aliran baru dari psikologi pendidikan yang lahir dari gagasan Peaget dan Vigotsky (para ahli dalam bidang kognitif) setelah terjadinya revolusi pemikiran ilmiah. Kedua tokoh ini menekankan bahwa perubahan kognitif hanya terjadi jika konsepsi-konsepsi yang telah dipahami sebelumnya diolah melalui suatu proses ketidakseimbangan dalam memahami informasi-informasi baru. (Anwar; 2017)

Menurut Cahyo dalam Anwar (2017) bahwa konstruktivisme merupakan salah satu aliran filsafat pengetahuan yang menekankan bahwa pengetahuan merupakan buatan kita sendiri. Pengetahuan bukan tiruan dari realitas, bukan juga gambaran dari dunia kenyataan yang ada. Pengetahuan merupakan hasil dari konstruksi kognitif melalui kegiatan individu dengan membuat struktur, kategori, konsep, dan skema yang diperlukan untuk membangun pengetahun tersebut.

Aliran konstruktivisme berpandangan bahwa pengetahuan harus diinterpretasikan sendiri oleh masing-masing individu sebagai respon yang tidak bisa ditransfer begitu saja. Pengetahuan juga merupakan proses yang berkembang secara berkesinambungan dan kontinyu bukan sekadar sesuatu yang sudah ada. Dalam proses ini, keaktifan seseorang sangat menentukan dalam perkembangan pengetahuannya. Sebab, pada kenyataannya, masih banyak peserta didik yang salah menangkap sesuatu yang diberikan oleh pendidiknya. 
Fakta tersebut menunjukkan bahwa pengetahuan tidak begitu saja dipindahkan, tetapi harus dikonstruksi sendiri oleh peserta didik. Oleh karena itu, peran pendidik dalam pembelajaran bukan pemindahan pengetahuan, melainkan hanya sebagai fasilitator yang berperan menyediakan stimulus berupa strategi pembelajaran, bimbingan dan bantuan ketika peserta didik mengalami kesulitan belajar, serta menyediakan media dan materi pembelajaran agar peserta didik merasa termotivasi belajar, sehingga pembelajaran menjadi bermakna. Sehingga, peserta didik dapat mengkonstruksi pengetahuannya secara mandiri. Aliran konstruktivisme ini memiliki implementasi yang sangat signifikan untuk pembelajaran, karena mendorong pembelajar berperan lebih aktif dan kreatif dalam belajarnya. Keaktifan dan kreativitas peserta didik merupakan akibat dari konstruksi mandiri peserta didik terhadap sesuatu.

Selain itu, teori konstruktivisme juga menciptakan keteraturan dan apresiasi dalam belajar. Proses belajar konstruktivisme merupakan proses belajar mandiri sehingga potensi individu akan terukur dengan jelas. Salah satu fokus teori ini yakni evaluasi pada penilaian proses. Teori ini menuntun peserta didik untuk mengkonstruksi pengetahuannya sendiri dengan merefleksikan pada pengalaman sebelumnya. Dengan begitu, dalam proses pembelajaran, penyelesasian materi dan hasil bukan sesuatu hal yang terpenting melainkan partisipasi peserta didik dalam belajar.

Wahana evaluasi UNBK, sebagai new media yang bersifat transparansi dalam peyajiannya, memicu siswa untuk aktif belajar mandiri. Siswa berperan aktif dalam membangun pengetahuannya mengahadapi ujian akhir. Terlihat di tahun-tahun sebelumnya ketika masih dalam UN Berbasis LJK, para siswa dulunya bernilai rendah pada UNBK atau tidak mencapai standar yang telah ditetapkan pemerintah, termotivasi dalam kegiatan belajarnya. Hal ini dibuktikan dengan angka yang meningkat 
secara signifikan setelah mereka melakukan tes susulan. Walaupun UNBK bukan merupakan syarat kelulusan untuk para siswa kelas XII SMA dan sederajat dan hanya untuk menjadi penentu masuknya siswa ke jenjang perguruan tinggi, para siswa terdorong dan termotivasi untuk belajar secara aktif untuk mencapai bahkan untuk melampaui standar nilai yang ditetapkan karena partisipasi belajar yang mereka miliki.

\section{d) Difusi Inovasi}

Difusi Inovasi adalah teori tentang bagaimana sebuah ide dan teknologi baru tersebar dalam sebuah kebudayaan. Teori ini dipopulerkan oleh Everett Rogers melalui bukunya, Diffusion of Innovations pada tahun 1964. Ia mendefinisikan difusi sebagai proses sebuah inovasi yang harus dikomunikasikan melalui berbagai saluran dan jangka waktu tertentu dalam sebuah sistem sosial. (Everett; 1991)

Lebih jauh lagi, difusi inovasi merupakan proses berkomunikasi dari ide, praktik, atau objek yang dianggap baru oleh manusia atau unit adopsi lainnya melalui strategi yang terencana dengan tujuan untuk diadopsi. Perubahan menjadi tujuan akhir yang diinginkan. Diseminasi informasi merupakan jalur pembangkitan kesadaran dengan merupakan tahap awal dalam proses ini. Tahap-tahap seperti kesadaran, minat, percobaan dan adopsi manjadi serangkaian dalam proses tersebut. Menurut Rogers (1991) langkah-langkah difusi tersebut adalah pengetahuan, persuasi atau bujukan, keputusan, implementasi dan konfirmasi.

Sebuah inovasi terdifusi dalam pola yang bisa diprediksi ke seluruh masyarakat diyakini oleh teori ini. Beberapa kelompok orang akan mengadopsi sebuah inovasi segera setelah mereka mendengar inovasi tersebut. Sedangkan kelompok lainnya membutuhkan waktu lama untuk kemudian mengadopsi inovasi tersebut. Exploded atau meledak akan terjadi ketika sejumlah orang banyak mengadopsi sebuah inovasi. Oleh karena, tulisan ini melihat teori ini dapat direfleksikan dalam komunikasi kelompok dan organisasi atas dasar konsep difusi inovasi yang menyebarkan ide-ide baru. Maka UNBK merupakan suatu media yang inovatif dalam bidang pendidikan untuk didifusikan dengan diseminasi melalui tahap-tahap proses 
kesadaran yang dijelaskan sebelumnya pada setiap satuan jenjang pendidikan dalam hal ini SMA dan SMK di Kendari.

Penelitian ini memperlihatkan kepada kita bahwa UNBK dapat menjadi solusi efektivitas waktu, efisiensi biaya, dan jawaban atas fenomena kecurangan Ujian Nasional yang selama ini berlangsung, terlebih lagi sistem ujian semi offline ini memotivasi para peserta didik untuk belajar lebih giat lagi mengingat mereka hanya akan bergantug pada dirinya masing-masing. Hal ini dikatakan oleh Kepala Sekolah SMAN 4 Kendari seperti berikut,

"Saya melihat UNBK ini sangat baik. Saya melihat para siswa sangat serius menghadapi ujian. Saya lihat mereka ada yang mencakar (corat-coret) matematika. Antusiasmenya sangat tinggi dan hal ini saya tidak lihat pada tahun-tahun sebelum diadakannya UNBK ini. Mereka tidak lagi bergantung sama orang lain terkait jawaban, tidak ada lagi tim kerja sama seperti fenomena-fenomea di UNPK. Juga dari segi siswa mereka mengatakan UNBK justru menampilkan tampilan soal yang berbeda dari UNKP. Kalau ujian nasional dengan pensil dan kertas, kertas soalnya membuat kami (para siswa) panik karena menampilkan langsung banyak soal dalam satu lembaran soal, sementara UNBK menampilkan satu per satu soal. Ini adalah pernyataan dari para siswa saya ketika telah melaksanakan UNBK. Tapi, hal yang berat untuk UNBK sendiri ialah 'image' dari UNBK sendiri, karena kalau melihat literasi media komputer dari para siswa ini saya kira tidak ada masalah karena masa mereka ini adalah masa melek media jadinya 'image' UNBK itulah yang membuat persepsi mereka agak takut”.

Peminjaman komputer dari sekolah-sekolah lain dan laptop siswa yang dijadikan menjadi client UNBK mengarahkan Sekolah-sekolah di Kota Kendari memenuhi syarat yang telah ditetapkan dimana mengenai persyaratan minimal infrastruktur UN CBT yang tercantum dalam Peraturan BNSP nomor 0058/SDAR/BSNP/IV/2016 Tentang Petunjuk Teknis Pelaksanaan Ujian nasional Berbasis Komputer/Computer Based Test (UNCBT) Tahun Pelajaran 2016/2017 terkait prosedur pelaksanaan Ujian nasional Berbasis Komputer/Computer Based Test (UN CBT). Peminjaman via sekolah-sekolah lain dan melalui orang tua siswa peserta ujian 
membenarkan adanya komunikasi yang efektif apabila seorang komunikator dapat mempersuasi komunikannya akan suatu pesan yang disampaikan mengandung unsur kesamaan meaning.

Keterlibatan personalia di bidang TIK, menjadi faktor pendukung lainnya pada penyelenggaraan UNBK. Walau dengan infrastruktur yang tidak mencukupi. Setidaknya, personalia-personalia yang ada tidak menambah beban sekolah tersebut yang sudah minim infratsruktur. Hal demikian sudah mempresentasikan syarat dari personalia UNBK yang mana sekolah penyelenggara UNBK harus memiliki orang yang mumpuni di bidang TIK, sesuai dengan POS UNBK BAB V/D/ Nomor 1 dan 2. Tak hanya sampai disitu saja, Sumber daya Manusia tersebut diberikan pelatihan yang telah ditetapkan Panitia UN Tingkat Pusat untuk menyusun petunjuk teknis penggunaan (user manual) dan bahan pelatihan bagi tim teknis provinsi, tim teknis kabupaten/kota, proktor, teknisi, dan peserta UNBK. Hal ini pula sudah ditetapkan dalam POS UNBK BAB III/Nomor 3 tentang Penyiapan Sistem UNBK, sehingga diperoleh darinya skema pengelolaan UNBK sebagai berikut,

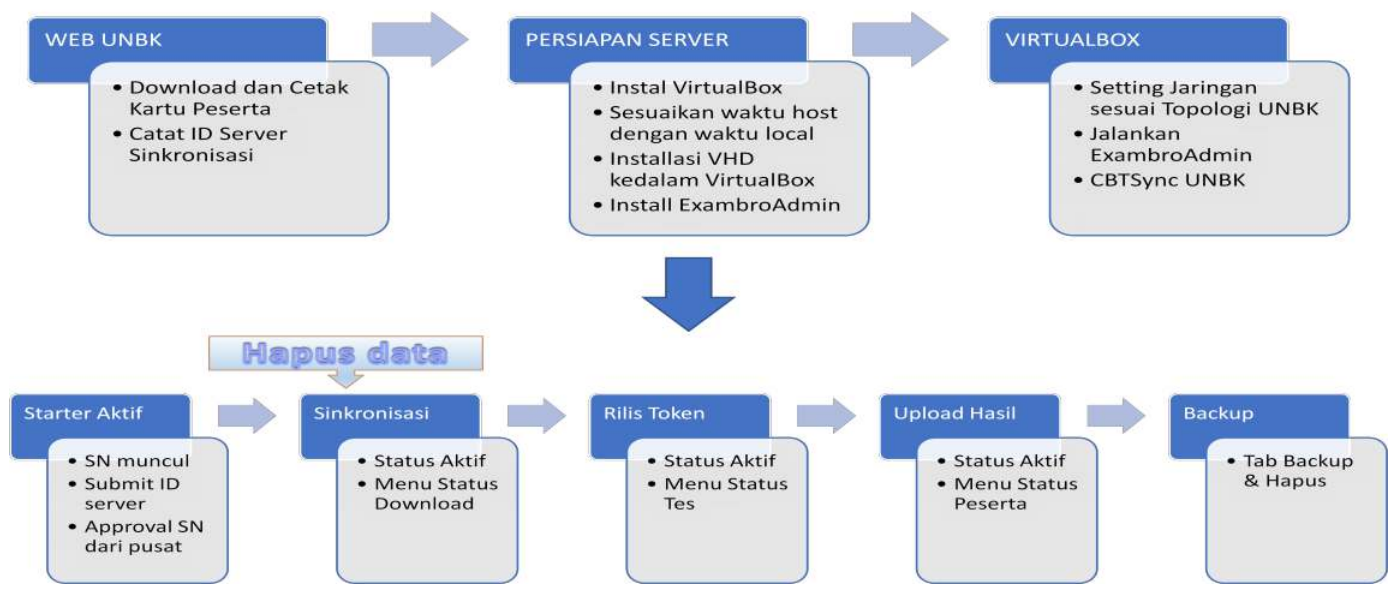

Bagan Hasil Seminar Materi UNBK Regional IV

Bagian terakhir menjadi faktor pendukung terselenggaranya UNBK di SMAN 4 Kendari pada tahun 2016 ialah kesiapan siswa itu sendiri. Pertama, bantuan dari para guru bidang studi yang melakukan pengayaan mata 
pelajaran UNBK memberikan kontribusi besar siswa dalam persiapan akan soal-soal UNBK. Kedua, simulasi UNBK oleh Kementrian Pendidikan Nasional pun mengarahkan para peserta ujian untuk mengetahui bagaimana mekanisme UNBK. Kedua hal tersebut bersinergi membimbing kesiapan siswa untuk melaksanakan UNBK, sehingga tidak ada lagi hambatan di bagian siswa itu sendiri. Lebih jauh lagi, motivasi belajar siswa untuk belajar secara mandiri terkonstruksi dengan penyelenggaraan UNBK sebab kesiapan yang dilakukan adalah untuk menjawab soal UNBK secara jujur akibat transparansi new media yang diberikan.

\section{KESIMPULAN DAN SARAN}

Tulisan ini menyimpulkan bahwa media baru memberikan dunia baru dalam pendidikan. Buah hasil Teknologi Informasi dan Komunikasi tersebut setidaknya mengubah aspek pendidikan pada satu sisi dengan transparansinya yang terimplemtasi dalam evaluasi pembelajaran. Media baru secara nyata memangkas pelbagai instrumen evaluasi belajar kesemua pihak yang terkait, pihak pemerintah dan pihak sekolah.

Berlandaskan teori yang relevan dalam tulisan ini. Tampak, media baru dalam asumsi teori new media, beriringan antara jarak kedekatan dan sifat keterbukaan. Media juga dalam segi esensinya menurut Luhan, membenarkan eksistensi perpanjangan tangan dari pemerintah ke pihak sekolah. Di sisi lain, dalam kajian konstruktivisme pendidikan, UNBK ini menjadi motivator para pembelajar agar berperan lebih aktif dan kreatif. Selain itu, dilihat dari kacamata difusi inovasi, ide, praktik, atau apapun dari media baru ini, pada awalnya dilalui dengan strategi terencana untuk diadopsi yang tujuan akhir yang ingin dicapai ialah untuk terjadinya perubahan. Terakhir, perubahan yang diinginkan dari media baru sejatinya membawa problem baru, namun kolaborasi dari semua aspek menjadikan 
media baru membawa kualitas pendidikan, efisiensi biaya, waktu, dan bahkan keterjangkauan jarak.

\section{DAFTAR PUSTAKA}

Abdulhak, Ishak \& Darmawan, Deni. 2013. Apa itu Teknologi Pendidikan Referensi Sebuah Arah Tujuan. PT Remaja Rosdakarya, Bandung.

Anwar, Chairul. 2017. Teori-teori Pendidikan klasik hingga kontemporer. IRCiSoD, Yogyakarta.

Bafadal, Ibrahim. 2008. Manajemen Perlengkapan Sekolah: Teori dan Aplikasinya. Bumi Aksara, Jakarta.

Bolter, Jay david; Grusin, Richard. 2000. Remediation; Understanding New Media. Garamond 3, ITC Goudy Sans; United States of America.

Cangara, Hafied. 2014. Pengantar Ilmu Komunikasi. Raja grafindo Persada, Jakarta.

Dessler, Gary. 2009. Manajemen Sumber Daya Manusia, Edisi Kesepuluh Jilid 2. PT. Macanan Jaya, Jakarta.

Everett M Rogers. 1991. Teknologi Komunikasi; Media Baru dalam Masyarakat; Penerjemah: Zulkarmaina Mohd. Mess. Percetakan yayasan Islam Kuala Terenggaru, Malaysia.

Green, Lelia. 2010. The Internet; An Introduction To New Media. Berg; New York.

Griffin, Ricky W. 2004. Manajemen. Jilid 1, Edisi Ketujuh; Erlangga, Jakarta.

Handoko, T. Hani. 2003. Manajemen. Cetakan Kedelapan belas. BPFE Yogyakarta, Yogyakarta.

Indrakusuma, Amir Daien. 1993. Evaluasi pendidikan. Penerbit IKIP MALANG, Malang.

Kriyantono, Rachmat. 2006. Teknik Praktis Riset Komunikasi. Prenada Media Group, Jakarta.

Lievrouw, L.A. dan Livingstone, S. (ed) 2006. The Handbook of New Media, $2^{\text {nd }}$ edn. London: Sage.

Lévy, Pierre. 2001. Cyberculture (Electronic Mediations). University of Minnesota Press, Minnesota.

Malayu, S.P., Hasibuan. 2009. Manajemen Sumber Daya Manusia cetakan 12. BumiAksara, Jakarta.

Moleong, Lexy J. 2004. Metode Penelitian Kualitatif. Rosdakarya, Bandung. 
Mulyana, Deddy. 2007. Imu Komunikasi Suatu Pengantar. PT Remaja Rosdakarya, Bandung.

Nurhidayat, Arif. Implementasi Ujian Nasional Berbasis KomputeratauComputer Based Test (CBT) Di SMA Negeri 1 Wonosari, di aksesdarieprints.uny.ac.id/34530/1/Arif Nurhidayat_11101244027.pdfpa da tanggal 27 Maret 2017.

Panduan Untuk Proktor Ubk/ UNBK Lengkap Dari Pra-Ujian, Pelaksanaan Ujian dan Pasca Ujian. Jawara Cloud. Diakses dari http://www.jawaracloud.net/2017/01/panduan-untuk-proktor-ubk unbk.html pada tanggal 25 Maret 2017.

Pedoman Penulisan Tesis dan Disertasi (Edisi 4) Program Pasca Sarjana Universitas Hasanuddin: 2012.

Peraturan Pemerintah No. 19 Tahun 2005 Tentang Standar Pendidikan Nasional.

Peraturan Badan Standar Nasional Pendidikan Nomor 0031/P/BSNP/III/2015 tentang Prosedur Operasional Standar Penyelenggaraan Ujian nasional Tahun Pelajaran 2014/2015 diakses dari http://bsnp-indonesia.org/ pada tanggal 2 April 2017.

Prawiradilaga, Dewi Salma. 2008. Prinsip Desain Pembelajaran, Penerbit Kencana Prenada Media Grup, Jakarta.

Rakhmat, Jalaludin. 2007. Psikologi Komunikasi. Bandung: Remaja Rosdakarya. Rohman, Arif. 2009. Politik Ideologi Pendidikan. Efendi, Yogyakarta.

Sanjaya, Wina. 2013. Kurikulum Pembelajaran: Teori dan Praktik pengembangan Kurikulum Tingkat satuan Pendidikan (KTSP). Kencana Prenada Media Group, Rawamangun: Jakarta.

Sobri, dkk. 2009. Pengelolaan Pendidikan. Multi Pressindo, Yogyakarta.

Sudiyono. 2007. Kebijakan Pendidikan. JurusanManajemen Pendidikan FIP UNY, Yogyakarta.

Sugiyono. 2009. Metode Penelitian Kuantitatif, Kualitatif dan R\&D. Alfabeta, Bandung.

Suharsimi, Arikunto. 2010. Evaluasi Program Pendidikan. PT BumiAksara, Jakarta.

Suwatno. \& Priansa, D. 2013. Manajemen SDM dalam organisasi Publik dan Bisnis. Alfabeta, Bandung.

UNDANG-UNDANG REPUBLIK INDONESIA Nomor 20 Tahun 2003 TentangSistem Pendidikan Nasional. 